\title{
Editorial: The boom in technology funds - Implications for the fund management industry
}

From saints to sinners - this is the recent view of the technology sector of global stock markets. Buoyed up by a frenzy of baby boom savings, which cascaded into Internet and related 'stories', technology stocks around the world had an incredible year in 1999. This was followed by a near bust in 2000 and a continuing slump in 2001. Does this mean that the boom in technology funds, which in the past decade have attracted a bigger slice of the investment pie in every major market, is over?

Absolutely not. Consider this: 15 years ago, the author was a Fund Manager for GT Management (now Amvescap) in the USA. We operated with faxes the size of fridges, and software was obscure, difficult to use and, from a stock market point of view, not as exciting as, say, airlines or retailers. In those days, this Editorial would have been hand-written, typed and then faxed or even telexed to its destination. Laptops, the Internet and MP3 did not exist. The world of the future was the world depicted in the film, 2001: Space Odyssey - exciting, but difficult to imagine. Video games were considered a fad, and Atari was on its way to the corporate graveyard.

Today, there is no one who cannot see that technology has impacted their lives, and almost no one who cannot see that the pace of change is accelerating. Where in 1985, vision was required to foresee that the PC would someday have utility and interconnectivity, today the questions are almost all about execution (ie how to get from here to a place we can clearly see) and disruption (an idea worth a billion today can be supplemented tomorrow by a better one).

Technology is rampant and will continue to be so. Mobile phones, we know, are just the blunderbusses of a new communications age.

Nanomechanics will revolutionise manufacturing procedures. The mapping of the human genome will significantly extend life expectancies for the typical adult in a developed country - ie those who can afford to pay for its application therapies.

'Old' economy industries, ranging from transport to mineral extraction, will also soon benefit from this unprecedented technological explosion. For example, it is quite possible that in a quarter of a century we will be living in a hydrogen economy, with fuel cells run on gas-powered automobiles and supplementing fossil fuels. All of these points have important implications for the fund management industry.

From a macro point of view, the key points are:

- Technology will become a large part of world GNP. In 1980 it was about 7 per cent of world GNP; today it is over 18 per cent.

- Baby boomers will live longer and therefore save more.

- New disruptive technologies will come along every couple of years, accelerating the cycle of creation and 
destruction of companies, and increasing volatility.

- Venture capitalists will become increasingly important and a significant retail venture capital (VC) industry will develop. Global VC will grow from US $\$ 40 \mathrm{bn}$ a year to well over US $\$ 100$ bn by the year 2005, although this year and next there will be a slump.

- The global technology fund sector will grow to over US $\$ 550$ bn in 2007 , almost five times last year's figure, representing a CAGR of 20 per cent.

This large pot of money will increasingly go to smaller, boutique managers, specialising either in entry-stage capital or in a specific area - either an area of industry or a geographical region. Major funds will find incentivisation of key managers to be a big problem and will have to introduce 'partnership' arrangements with the best and the brightest to retain them. This will subtract from gross margins but, since the funds carry typically two and a half times the economic reward (including performance fees) of broader industry, this can and should be justified. The best managers are those that are members of the 'magic circle' - ie the earlier components of the capital food chain. These managers have access to the really profitable early-stage deals and will typically produce much better results than the more staid 'old technology' managers. These managers are hard to come by, and increasingly come from an engineering background, rather than a purely financial one.

In the immediate future, there are significant risks to consider for investors and fund managers, and their employees in technology:

- High valuations: Despite the fall in technology stocks, valuations are still overstretched and assume exponential growth for years to come. A good example is Cisco Systems, the world's leading producer of Internet routers and networking products. It is a phenomenal company, but its market valuation (current market cap US $\$ 125 \mathrm{bn}$ ) an infinite multiple of this year's earnings and probably 200 times next. If Cisco were a small company, a price like this might be justified, but it is no longer small and so is subject to the law of diminishing growth: the bigger a company gets, the harder it is to grow. Yet fund managers running increasingly large funds are almost forced into crises because of their size.

- Replication risk: A company like Cisco depends on maintaining a proprietary lead in its technological area to maintain growth. If a new entrant to the market produces a similar product at an equal or lower price, prices, growth and profits will fall. A case in point is Intel, which is now suffering intense competition from AMD and will soon face very tough challenges from the Transmeta Crusoe Chip.

- Disruptive technologies: These are technologies that can change a marketplace overnight. The Internet was one such technology. It transformed the way in which we distribute and store information, and it will alter (but not as fast as people initially thought) the way we act in daily life. An example: Manufacturers of buggy whips were very comfortable until the invention of the car, then overnight they were gone. One company that has a disruptive technology, albeit in a mundane field, is Align Technologies. They have taken the familiar dental brace and transformed it into something that is invisible, easy to wear and cheap. They will control a multibillion dollar 
market place and will prove an excellent investment. Align is now listed on Nasdaq (c. US\$7 per share).

- Food chain risk: Private investors only get to see deals when the venture capitalists have already drunk the cream or want to get out. They should stick to investment in good professionally managed funds for their investment in technology. It is too hard for those not in the "magic circle' to make money. Furthermore, because the market in technology stocks is so volatile, diversification is a real key to success. As an investor, I would recommend looking for small, specialist funds rather than bigger funds which invest only in established (and fully valued) stocks. Also, it makes sense to invest in funds that are internationally diversified - the UK ranks low in terms of technological innovation turned into profits. This means that fund management companies should 'slice and dice' their offerings, having, rather than one big 'technology' fund, a series of smaller, more nimble offerings which can do earlier-stage things.

- Economic risk: The US economy is slowing significantly. Capital will become even tighter and stock markets continue to be uncertain, one-third of its high. This phase should last for three years and, in that time, stocks will be unexciting; even the 'golden age' stocks will not do as well. Investors can wait to make commitments for a little while longer. The Nasdaq index as of 20th August was at around 1,881 . It could sputter to 1,500 or so. At that point, things will look very interesting.

Other implications of technology for the fund management industry, of course, include the electronic distribution of funds. Increasingly, fund management will be made more transparent by the disintermediation of the Internet, and by the linkage of sites which will compare and price various options. Companies such as Eurobenefits will provide instant data on future asset growth and liabilities and individuals into pension funds, and it will become harder for fund managers to hide poor performance. In addition, as we are already seeing, there will be a greater attention to commissions and loadings on financial services which will diminish front end margins for the industry. Traditionally, they have supported heavy advertising campaigns and so fund managers will increasingly look for (technology-based) ways of increasing the effectiveness of advertising campaigns and of reducing costs. For example, vital or guerrilla marketing will be increasingly used by fund managers. Investing in technology will typically be increasingly effectively outsourced to application service providers (ASPs) specialising in front office and back office funds for fund managers.

To conclude, the growth - both absolute and relative - of technology funds will continue post a period of near carnage as a result of huge and excessive valuations. Increasingly, boutique managers, or 'managers within managers' will spring up, the average fund size will come down, and the way in which funds are distributed will change. However, this remains absolutely the most important sector and is ignored at the peril of any serious fund management business.

Jim Mellon, Chairman iRegent Group Limited August, 2001 